\title{
Somogy megye Isopoda faunája (Isopoda: Oniscidea)
}

\author{
FARKAS SÁNDOR - VADKERTI EDIT
}

FARKAS S. - VADKERTI E.: Isopoda fauna of Somogy county (Isopoda: Oniscidea)

Abstract: The checklist of terrrestrial Isopoda from Somogy county (south-west Hungary) covers 16 species. The history of the scientific investigations of Oniscidea of this region is briefly reported.

\section{Bevezetés}

Az Oniscidea csoport (szárazföldi ászkarákok) az Arthropoda törzs, Crustacea altörzs, Malacostraca osztály, Eumalacostraca alosztály, Edriophthalma rend, Isopoda alrendbe tartoznak.

Annak ellenére, hogy Magyarország Isopoda faunájának kutatása mintegy 150 évvel ezelőtt már megkezdôdött, az ország területének kb. $90 \%$-áról a mai napig sincs a csoportra vonatkozó, publikált faunisztikai adat.

Somogy megye Isopoda faunájáról 1996-ig négy publikáció jelent meg, tíz lelóhelyi adattal. DuDICH (1925) közli a Platyarthus hoffmannseggi előfordulását Balatonszemesról és a a Trachelipus nodulosus-t (1942) Siófokról. Három további faj került elô a Barcsi Borókás Tájvédelmi Körzetból: a Trachekipus rathkei, T. ratzeburgi és az Armadillidium vulgare (LANTOS 1985). A következö öt fajt egy ökológiai vizsgálat során találták Balatonberény és Balatonmária között, egy pontosabban nem megjelölt lelöhelyen: Porcellium collicola, Armadillidium versicolor, A. vulgare, A. zenkeri, és Hyloniscus sp. (SZLÁveCz 1992).

A Dél-Dunántúl Oniscidea faunájának szélesebbkörú kutatása 1996-ban kezdődött. Somogy megyében, elsősorban a Rinya árterének Segesdtól Péterhidáig terjedố szakaszán és a Dráva árterén történtek mintavételek. A kutatások során további hat faj került elő (FARKAS 1998a, 1998b, 1998c, 1999a, 1999b), így 16-ra emelkedett a területról ismert fajok száma, mely a hazai fauna $36 \%$-át teszi ki.

Magyarországról eddig 42 Oniscidea fajt mutattak ki (FORRó és FARKAS 1998). Somogy megye területe az említett kutatás ellenére is csak kb. 1\%-ban feltárt. Bár az ászka populációk nem random elöfordulásúak, szoros élóhely preferenciát nem mutatnak, így további fajok előfordulása várható (FARKAS 1999b). 


\section{Somogyból ismert fajok jegyzéke}

Ligiidae

Ligidium hypnorum Verhoeff, 1901

\section{Trichoniscidae}

Calconiscellus karawankianus Verhoeff, 1907

Haplophthalmus mengii Zaddach, 1844

Hyloniscus riparius (C.L. Koch, 1838)

\section{Platyarthridae}

Platyarthrus hoffmannseggii Brandt, 1833

\section{Cylisticidae}

Cylisticus convexus De Geer, 1778

\section{Porcellionidae}

Porcellio scaber Latreille, 1804

\section{Trachelipidae}

Porcellium collicola Verhoeff, 1907

Protracheonicsus amoenus (C.L. Koch, 1841)

Trachelipus nodulosus (C.L. Koch, 1838)

Trachelipus rathkei Brandt, 1833

Trachelipus ratzeburgi Brandt, 1833

\section{Armadillidiidae}

Armadillidium opacum (C.L. Koch, 1841)

Armadillidium versicolor (Verh., 1901)

Armadillidium vulgare Latreille, 1804

Armadillidium zenkeri Brandt, 1833

\section{1. táblázat: Somogyból ismert fajok száma családonként}

\begin{tabular}{|l|c|}
\hline Család & Fajszám \\
\hline Ligiidae & 1 \\
\hline Trichoniscidae & 3 \\
\hline Platyarthridae & 1 \\
\hline Cylisticidae & 1 \\
\hline Porcellionidae & 1 \\
\hline Trachelipidae & 5 \\
\hline Armadillidiidae & 4 \\
\hline
\end{tabular}

\section{Irodalom}

Dudich, E. 1925: Faunisztikai jegyzetek (Faunistische Notizen) I. -Állatt. Közl. 22: 39-46.

DudicH, E. 1942: Nachträ und Berichtigungen zum Crustaceen - Teil des ungarischen Faunenkataloges II.-Fragm. Faun. Hung. 5:1-13.

FARKAS, S. 1998a: A Rinya-ártér Isopoda faunája I. Bakháza. - Somogyi Múzeumok Közleményei. XIII. 257-262.

FARKAS, S. 1998b: Az ászkarák (Crustacea: Isopoda) kutatások faunisztikai eredményei a Dráva mentén. - Dunántúli Dolgozatok Természettudományi Sorozat, 9: 123-130.

FARKAS, S. 1998c: The terrestrial isopod fauna of the Rinya region II. Péterhida. Miscellanea Zoologica Hungarica, Tomus 12: 45-53.

FARKAS, S. 1999a: Egy tölgyes és egy fenyves állomány Isopoda együtteseinek szünbiológiai vizsgálata a Rinya-ártéren III. Nagyatád - Kivadár. MTA Ökológiai és Botanikai Kutatóintézet kiadványa - szerk.: Botta Dukát Zoltán, Vácrátót (accepted - in press)

FARKAS, S. 1999b: Isopodák szünbiológiai vizsgálata a Dráva-ártéren. PhD értekezés - JATE, Szeged

FORRÓ, L., FARKAS, S. 1998: Checklist, preliminary distribution maps, and bibliography of woodlice in Hungary (Isopoda: Oniscidea) - Misc. Zool. Hung. 12: 21-44.

LANTOS, G. 1985: Amphipoda és Isopoda faunisztikai adatok a Barcsi Borókás Tájvédelmi Körzetból (Amphipoda and Isopoda (Crustacea) data from the Barcs Juniper Woodland nature preservation area, Hungary). - Dunántúli Dolg. Term. Tud. Sorozat 5: 89-92.

SzLÁVECZ, K. 1992: The role of terrestrial Isopods (Isopoda: Oniscidea) in the decomposition of aquatic macrophite detritus of Lake Balaton, Hungary. - Opusc. zool. Budapest, 25: 103-112. 


\title{
Isopoda fauna of Somogy county (Isopoda: Oniscidea)
}

\section{SÁNDOR FARKAS \& EDIT VADKERTI}

Although the studies on the Hungarian Isopoda fauna started 150 years ago, only four fanistical data were documented only four fanistical data from Somogy county untill 1996. DUDICH (1925) reported Platyarthrus hoffmannseggii from Balatonszemes and Trachelipus nodulosus from Siófok (DUDICH 1942). Three species were found at Barcsi Borókás: Trachelipus rathkei, T. ratzeburgi, Armadillidium vulgare (LANTOS I985). Five species were found at Lake Balaton between Balatonberény and Balatonmária: Porcellium collicola, A. versicolor, $A$. vulgare, A zenkeri and Hyloniscus sp. (SZLÁveCZ 1992).

An intensive research started in 1996 along the Rinya stream and the inundation area of the River Drava. Further six species were found in this area (FARKAS 1998a, 1998b, 1998c, 1999a, 1999b).

Present paper summarizes the results of Oniscidea fauna-researches of Somogy county. Untill recently, 16 species $-36 \%$ of the Hungarian fauna (FoRRÓ and FARKAS 1998) - were documented. $99 \%$ of this area is undiscovered.

\author{
Author's addresses: \\ Dr. Sándor FARKAS \& Edit VADKERTI \\ Department of Zootaxonomy and Synzoology, \\ Biological Institute, University of Pécs \\ H-7624 Pécs \\ Ifjúság u. 6 . \\ HUNGARY
}

